\title{
PRACTICAL MODEL OF INDIGENOUS CO-CREATION FOR THE SUSTAINABILITY OF INDONESIAN WOVEN SONGKET
}

\author{
Kusumastuti, Retno ${ }^{\mathrm{a}}$; Umanto ${ }^{\mathrm{b}}$ \\ Administrative Science Faculty, University of Indonesia, Indonesia
}

\begin{abstract}
Innovation is the main key to the sustainability of all industries. Fashion industry with traditional woven as its basic material is one of complexindustries for its association with social environment in all cultural values, market taste, chain value, life cycle products and even government policy. This focus will likely be important as indigenous characteristic in the traditional woven becomes the competitive advantage of a region. The outcome of this study showed that traditional woven co-creation in design need an involvement of social actors in the social learning process. Indigenous co-creation of traditional woven is a social innovation learning activities that needs adequate involvement of actors and context. The purpose of this study is to analyze the challenges and constraints for the sustainability of Indonesian woven songket and to develop a practical co-creation model in attempt to cope with various constraints to generate recommendation for decision makers at local goverment level. This study used qualitative approach. The primary and secondary data to answer the research questions were collected through in-depth interview and focus group discussion.
\end{abstract}

Keywords: Indigenous Co-creation, Social Innovation, Competitive Advantage 


\section{INTRODUCTION}

Asean Economic Community (MEA) which is designed as an economic integration model in the Asean region has created the opportunity for transparency in the trade of goods, services, investment, capital and labors. It put demands on domestic production to achieve quality products competitive to foreign products/services. Hence, innovative practices, both explorative and exploitative, must be promoted to generate uniquely competitive and nonimitable products.

There is growing demand for each industry to innovate, including textile industrial products especially. This industry is facing complex issues due to its long chain value, which involve the context of socio-cultural value and even government policy as relevant. The Ministry of Trade announces the importance of fashion products by reference to data in the period of 20082013 reaching 19\% growth (www. kemendag.go.id.).

One of the potentially high competitive domestic products is that with unique and non-imitable characteristics. One of the sources of Competitive Advantage is culture and its community (Barney and Hesterly, 2010). Typical traditional cloth produced on a local courtesy basis, is therefore, a very strategic national cultural product to compete at global level if supported by conducive business climate through proper policy.

In addition to Batik which is internationalized, Indonesia has center for sasirangan cloth, center for embroidered textile and center for woven textile (Bank Indonesia, 2015). This research will focus on how co-creation process in the social innovation learning generate Indonesian typical traditional cloth works on local courtesy basis by empirical study on songket woven cloth craftspeople. Woven songket cloth highly relies on the creativity of its craftspeople, then the human value and underlying social-cultural context is very important. This becomes a valuable input for the decision makers to create conducive business climate to promote the business of traditional cloth craftspeople to actively compete in era MEA.

The importance of innovation was recognized by some well-known craftspeople. Zainal Palembang songket expressed that innovation will usually occur in terms of color selection, design and diversification of business (www. radar-palembang.com, 2014). Woven cloth crafts people in Bali began using natural dye in their works and weaving equipment for songket cloth without joint (www.suara.com, 2016). Susilawati from Jambi has even made her own innovation by combining songket patterns on light and practical handwoven cloth which is washable (www.langitperempuan.com, 2016). The point is that the innovation on traditional cloth especially songket must not disregard the value of local courtesy which is typical character of the region. Inquiries on woven songket works become unique due to the long production process with traditional weaving equipment which requires special skills and off course it needs ability to understand the underlying cultural values of the pattern and decorations. The uniqueness of songket woven has been internationally recognized in some neighbouring countries such as Malaysia and Singapore.

Songket woven is the work of local nation youth which symbolizes the greatness of the users. This is reflected by the arrangement of golden linen tidely arranged with certain patterns, which represent the skills of indigenous inhabitants inherited from generation to generation. The existence of local people as a producers of songket woven 
is not apart from the cross-generation learning process as a representation of local culture which becomes the philosophy of life, social value and tradition of local communities. Learning process of songket woven from one to another generation or among individuals and group of local people needs to be identified, managed and developed to generate new works (mainstream and newstream) to develop local and national competitiveness.

The local producers of songket woven cannot do it individually and partially per region. The study exposing the importance of government support for promoting Social Innovation at local level reveals that the government needs to design incubation program especially for start-up, accelerated funding for UMKM and protection of patent right (Lee, 2014). Interview with the Director of UMKM Development in Bank Indonesia also reveal that the patent right at UMKM level remains to be improved (Interview with Fitriani, Director of UMKM Development Bank Indonesia, 2015).

\section{THEORETICAL FRAMEWORK AND PREVIOUS STUDIES}

Co-creation plays important role in generating Competitive Advantage for the company. Voorberg, Bekkers, and Tummers (2014, p.2) even stated that co-creation contributes not only to the satisfaction and loyalty of customers, but also for the company in creating.

Voorberg, Bekkers, and Tummers (2014, p.2) said that there are two trends in the discussion on co creation in private sector. First, the capacity of the company in manufacturing goods and services in more efficient manner. Second, the emergence of end users who may serve as co creators through experience in using the goods and services which provide added value for the company.
In analyzing the innovation of learning process on songket woven cloth, this research used Social Innovation model developed by Moulaert et.al (2013) and Nonaka, et.al (2008). Moulaert, et.al (2013) developed four stages in the Social Innovation process starting from idea generation, piloting, implementation and scaling. Besides using the model developed by Moulaert (2013), this research also used the model developed by Nonaka, et.al (2008). In the perspective of Nonaka, et.al (2008), knowledge creation process consists of four stages divided into socialization, externalization, combination and internalization at individual, group and organization level.

Learning model from Nonaka knowledge creation model is generally applied in the corporate context with more structural innovation learning. State of the art of this research is that how the model applied in the different context. According to Kusumastuti, creation of new knowledge at micro, small and medium scale business scale also occurs at contextual level (Kusumastuti, et.al 2015). To explore how traditionally songket cloth can have Competitive Advantage, the resource based view perspective (Barney and Hesterly, 2010) is used to explore the primary source of Competitive Advantage namely People and Culture. State of the art in this study is the theoretical adalah innovation which combine the perspective of Moulaert, et.al (2013) and Nonaka, et.al (2008), and practical side of research team focus on traditional cloth with indigenous characteristics with high local wisdom in the learning process of innovation.

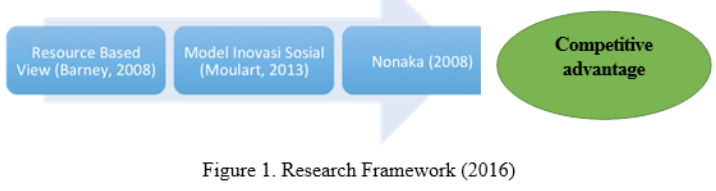




\section{RESEARCH METHOD}

This research used qualitative approach on inductive model namely the concept of social Innovation and co-creation. Qualitative research focused on the process that is occurring as well as the product outcome. Researcher are particularly interested in and understanding how things occurs (Creswell, 1994, p.164). This research focused on the co-creation process occured and researchers played important role in understanding the co-creation as a social phenomenon observed. The researcher explored in more detail and comprehensively the learning process of social innovation in the making of traditional cloth of the local people with local and cultural values of the surrounding communities.

This research used qualitative method to generate comprehensive analysis on the issues of research. Qualitative method was applied through in-depth interview with some informants and site observations. Interview guideline was prepared using the theory on the learning process of knowledge creation, co-creation and social innovation and perspective of resource based view to explore the source of competitive advantage of traditional cloth with understanding of the production process, business process, cultural and local values and the policy context related to traditional textile industry in such region.

\section{RESULT OF RESEARCH}

Analyzing the activities of social innovation learning by traditional woven by indigenous people, may refer to the approach proposed by Prahalad with regard to social innovation which emphasized on sustainability driven innovation (Little, 2006). This is based on business indication by the indigenous people to maintain the sustainability of songket woven through explorative and exploitative innovation by finding the methods, technique, products, process and even the new market segment. With regard to this perspective, the occurring Social Innovation will provide added value to the business, community and environment (CII-ITC CESD, 2010). In traditional perspective, innovation activity is the internal responsibility of an organization, which at certain point cannot capture market trend. Nonaka, et.al (2008) presented the learning concept to generate new knowledge through co-creation activity. The cocreation concept will be observed as to its process in the context of Social Innovation learning based on human interaction.

The state of the art of this research is combining mind frame the cycle of Social Innovation by Moulaert, et.al (2013) with co-creation learning of Nonaka, et.al (2008) for innovation of songket woven which is depicted in Figure 2 below:

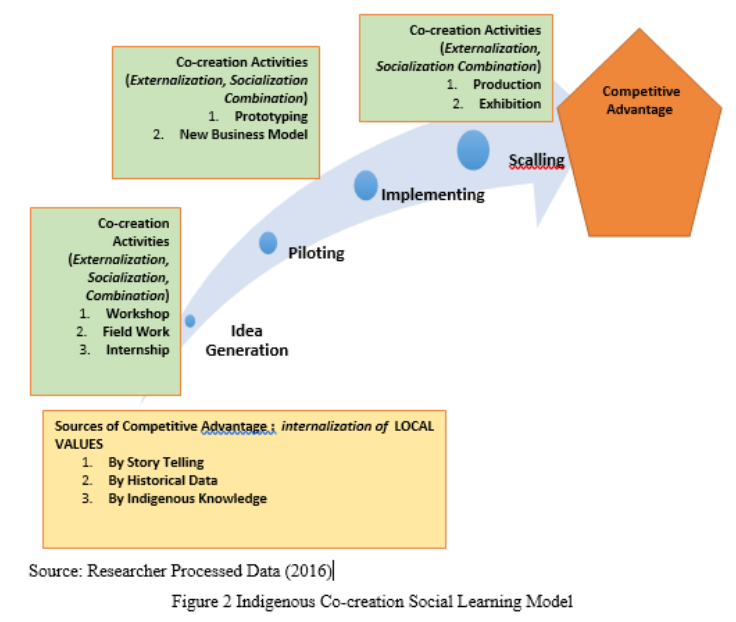

Some innovations in the development of traditional cloth products for Batik in Java involved the new production technique (Sawitri, 2008). Songket cloth innovated in terms of production technique and expands use of basic materials but also diversification of products to purses, sandal shoes, caps 
and et cetera. Songket with certain quality has been used as the basic material of luxurious fashion with innovative design combined with Japanese Kimono (www.republika.co.id.). The application of songket to modern lifestyle such as dining equipment has also started (gayahidup.republika@co.id.). Each pattern of songket woven cloth embodies the meaning on local courtesy.

\subsection{Diversity of Indonesia Traditional Woven Songket Cloth}

Some of the traditional diversities in Indonesia typical traditional woven cloth songket can be explained as follows:

\section{Padang Woven Songket}

In its original pattern, it has high difficulty level which is hard to find nowadays. One of the popular patterns is Saluak Laka which consists of straight line and curved lines. This ornament implies two kinds of relationships in Minang Kabau, religion with the straight line and custom with the curved line. If observed further, saluak laka is interwoven coconut leaf sticks or rattans made to support and raise the pot. The meaning of this ornament is solidarity implying theres is always solution to any kind of problem.

\section{Sumbawa Woven Songket}

The pattern of woven songket in Sumbawa is highly ornamental namely selimpat, lonto engal, kemang setange, pohon hayat, lasuji, pusuk rebong, geometrical gelampok, cepa, rooster, human, bangka, wapak. All these ornaments have their unique meanings. Globally, the symbolical meaning of the ornamental pattern represents the forms of kinship, solidarity and harmonization with the surroundings in their daily lives.

\section{Palembang Woven Songket}

The Palembang traditional weaving craftworks is the acculturation from China and India. The predominance of dari Palembang ornamented woven songket is the cave dragon showing symbolizing the welfare and prosperity in life. Besides, there is a tip of bamboo sprout showing that the users will be useful for the communities. The flower patterns of cloves and others symbolize the sacredness, elegance, livelihood and kindness.

Local courtesy to be explored and revealing the identity of traditional user of woven songket cloth is sacredness, beauty, diligence, patience and precision. Sacredness can be seen in the use of traditional songket cloth in vital and religious ceremonies. Precision and patience is reflected from the production which requires extended duration and complex techniques. The beauty is reflected from the highly artistic ornamental which is the combination of woven gold linen.

4.2 Co-creation in the learning process of Social Innovation

Why social innovation learning should be approached with co-creation?. This Nonaka Perspective has likely become important as creating traditional songket woven cloth will require sharing of ideas between the stakeholders in the community. The meaning of pattern and ornaments relied not only on face to face interview but also the meaning embodied. This is consistent with the opinion that co-creation contains the process for sharing sense of value (Hirano, et.al, 2013). In addition, the main benefit in the collaborative innovation or co-creation will also generate emotional bond among those in the learning process of innovated works as their joint identity which should be collectively preserved.

\section{Source of Competitive Advantage}

The embryo in crafting traditional cloth is the stage to determine the style of ornaments for the patterns of woven cloth. Determining a pattern must be first consented by the traditional community leaders in the past. The results from the 
exploration by the team of historians from Andalas University showed that there are hundreds ornamental styles in Padang woven cloth with different meanings. The exploration on patterns and ornamental styles of woven songket can be identified by story telling of the community leaders or traditional craftspeople.

At present, the learning process for innovation cannot be complete individually. Craftspeople will usually gather in an association or group of entrepreneurs who are also craftspeople. For example, Zainal Songket from Palembang and Ghea Sukasah gathering some craftspeople in a joint workshop and tranings to produce innovative woven cloth. Recently, World Economis Islamic Forum (2016), small and medium scale entrepreneurs in traditional cloth gathered to share knowledge on innovation activities through a collaboration.

Some new technology applications and techniques in the production or distribution channel have changed the model of business. Traditional model of the craftspeople originally used household for production and distribution channel has changed a lot among the craftspeople, association and government support through UMKM office. At present, the production house is separated from the distribution channel. Some events have been facilitated by the government in the form of integrated exhibitions at local and international level.

The remaining constraints of the craftspeople need to be improved by the government such as pilot age program for optimized funding at micro, small and medium scale, business development and innovation of woven cloth.

\section{Social Innovation Process}

The occurring Social Innovation in the traditional cloth tenun songket in Palembang, Padang and Sumbawa represent the model of procedure and action of the craftspeople of songket woven cloth relating to the stage of creation, combination and expansion of Social Innovation. Basically, this process is a cycle. Based on the perspective that Social Innovation process starts from abstraction which transforms into reality and re-abstracted after reaching its highest form (Kusumastuti, 2013). Most Social Innovation activities are done by the community. Indonesia traditional textile crafting is also activity by the community craftspeople as the result of learning process from one to the successive generation. It usually involved female youths before entering marriage or housewives while waiting for shalat time. Social innovation activities in woven songket is female activities and dependent on the creativity of women.

The social innovation activity consists of the following learning process at some levels:

\section{a. Individual Learning}

At this level, each individual contemplates in search of ideas related to ornamental style, pattern or diversifications which can be explored from songket woven cloth. Lee (2014) mentioned this as a creation phase. In the next step, they usually identify the problems faced. In finding the solution to this problem, they will usually find sources through information, knowledge available and even read literatures, observation or other source of information. In the learning context of Nonaka, et.al (2008), this phase is termed internalization learning.

\section{b. Group Learning Level}

Information sharing through discussion among craftspeople, traditional songket cloth entrepreneurs or other community members will organize "forum" as a "study group" jointly seeking the solution to the problems faced. This phase is termed as 
externalization because the craftspeople exchange information using the relevant materials with songket woven cloth. The generators of this group are usually predominant craftspeople with good leadership and ability to manage groups in articulating the interest of the group.

\section{c. Organization Learning Level}

The formality of study group is later formalized in a form of association or "paguyuban" of traditional songket woven cloth craftspeople. At this level, this innovation activities are formally introduced to the community. This activities, according to Nonaka, are included in the socialization learning matrix. The benefit from the learning activities will receive inputs from the customers and other parties which create link and match between the producer and consumer. This phase is called, by Lee (2014) as integration phase, as simultaneously members of the group or organization publish their innovative works so community support can be developed. This condition is called Social Innovation integrated with the community. In the context of songket cloth craftspeople, if innovative textile products have been widely used, the trend to wear songket will rise. At present, the phenomenon of social change has occurred in the community.

Expansion phase according to Lee (2014) will have occurred after traditional woven cloth songket enter the global market, widely recognized as a work of the nation. However, this learning process will not stop because when innovation expands, as combined with Japanese Kimono style into the design of songket cloth, this is the real phase when combination learning process occurs. Indonesia traditional songket cloth with local courtes value will later be combined with Japanese cultural value in Kimono design which generate innovation to capture domestic and global markets.

\section{CONCLUSION}

Social innovation learning model in Indonesia traditional songket cloth craftspeople start from the phase of generation, piloting, implementation and scaling through co-creation. Co-creation learning process occurs in a cycle from the abstraction to the highest form which later transforms into evolving innovation of inovatif traditional cloth which grow explicatively and exploitatively. Innovation of traditional songket woven cloth is not apart from the typical local value. Despite the change in colors, crafting technique and materials, it preserve the ornamental style and patterns with particular meanings. This uniqueness cannot be imitated and must be managed and developed to generate Competitive Advantage as a national identity.

\section{REFERENCES}

Ainiyah, N., Deliar, A., \&Virtriana, R. Barney, J. B., and William S. Hesterly, (2010). Strategic Management and Competitive Advantage: Concept and Cases (5th edition). Pearson Prentice Hall Inc

Creswell, John W., (1994), Research Design:QualitativeandQuantitative Approaches, California: SAGE Publications, Inc

Creswell, John W., (2010), Research Design: Qualitative, Quantitative, and Mixed Methods Approaches 3rd Edition, SAGE Publications, Inc

Hirano, Takashi., Akihiko Ishizuka, and Kazutoshi Sakaguchi, (2013), Innovation Activities by co-creation, Fujitsu Science Technology Journal., Vol. 49, No. 4, pp. 391-396, October 2013.

Kusumastuti, R. (2013), Membangun Keunggulan Bersaing melalui 
Dual Ambidexterity pada Lippo Karawaci: Aplikasi Multi Metodologi Cognitive Map dan Soft Systems Methodology Kontinum Dual Imperatives, Disertasi. Departemen Ilmu Administrasi, Faklutas Ilmu Sosial dan Ilmu Piolitik, Universitas Indonesia.

Kusumastuti, Retno., Safitri, Nurul., Khafian, Nidaan, (2015), Developing Innovation Capability of SME through Contextual Ambidexterity, Jurnal Bisnis dan Birokrasi, Vol. 22 No. 1.

Kusumastuti, Retno, (2017), Innovation diagnostic of micro, Small and Medium Enterprises (SME): A comparative study of innovation process of SMEs in Depok and Solo, Volume 15, Issues 20, 2017, https:// www.scopus.com/record/display. uri?eid=2s2.085032571360\&orig in $=$ resultslist $\&$ sort $=$ plff $\& s r c=s \& s$ $\mathrm{id}=9$ deoa116fea $7482 \mathrm{e} 20848 \mathrm{fecc} 3$ $730 b_{5}$ a\&sot $=$ autdocs\&sdt $=$ autdo cs\&sl=18\&s=AU-ID\%2857192662578\%29\&relpos

Lee, Peter, (2014), Social Innovation, Washington University Law Review, Volume 92, Issue 1.

Little, Arthur D, (2006), The Innovation High Ground: Winning Tomorrow's Customers Using SustainabilityDriven Innovation, Strategic Direction, Vol 22, Issue 1

Moulaert, Frank, Diana MacCallum, Abid Mehmood, and Abdelillah Hamdouch, (2013), International Handbook of Social Innovation : Collective Action, Social Learning and Transdisciplinary Research, Edward Elgar Publishing Limited, Cheltenham UK

Nonaka, Ikujiro, Ryoko Toyama, and Toru Hirata, (2008), Managing Flow: A Process Theory of Knolwedge-Based Firm, Palgrave
MacMillan

Sawitri, Sicilia, (2008), Pengembangan Produk Tekstil pada Usaha Industri Kecil Menengah Batik Tradisional dan Sutera Jawa Tengah, Teknobuga, Volume 1, Nomor 1, April 2008.

Voorberg, W.H, V.J.J.M Bekkers, and L.G. Tummers, (2014), A Systematic Review of Co-Creation and Co-Production:Embarking on the Social Innovation Journey, Public Management Review

\section{Sumber Lain}

www.kemendag.go.id

www.republika.co.id., Adrian Gan sulap songket menjadi pakaian yang mewah dan edgy, Mei 2016, diunduh pada 3 Agustus 2016 pukul 15.35 wib.

www.gayahidup.republika.co.id, Menparekraf mengapresiasi aplikasi songket pada gaya modern, Maret 2014, diunduh pada 3 Agustus 2016 pukul 15.35 wib.

www.radar-palembang.com, Oktober 2014, Pertahanannya adalah inovasi, diunduh pada selasa, 2 Agustus 2016, pukul 16.00 wib.

www.suara.com, Juli 2016, Inovasi pengrajin songket agar tidak disudahi jaman, diunduh pada selasa, 2 Agustus 2016, pukul 18.35 wib. 